\title{
Towards Community-based Landslide Preparedness in Malaysia
}

\author{
Khairiah Salwa Mokhtar ${ }^{1}$, Habibah Lateh ${ }^{2}$ \\ ${ }^{1}$ Political Science Department, School of Distance Education, Universiti Sains Malaysia \\ ${ }^{2}$ Geography Department, School of Distance Education, Universiti Sains Malaysia
}

\begin{abstract}
There is an urgent need to develop an apt program for improving the society resilience in facing natural disasters. This program must be distinctively characterized according to different prone areas in order for it to be more effective in its implementation. A more focused preparedness program is expected to reduce the risks of disaster. In order to develop suitable preparedness program, the community preparedness towards natural disaster has to be gauged. Thus, this article examines the relationship between demographic variables and four key construct of community preparedness, namely attitude, knowledge, practice, and awareness towards landslide. Three particular sites in Malaysia, based on their unique characteristics, are chosen for this goal. The results call for developing community-based preparedness program, which should be aligned with each specific region characteristics. The implications of the study address considerably different approaches for each region. The article concludes with some limitations of the study and avenues for future related research.
\end{abstract}

Keywords: Landslide, Awareness, Preparedness, KAP, Malaysia.

\section{Introduction}

South East Asia suffers from geological disasters such as earthquake, tsunami, landslide and floods [1, $2]$ which usually cause great loss to both life and property [3,4]. When disasters are unavoidable, minimizing its consequences especially by saving lives is vital [5]. Developing an appropriate strategy is essential to reduce the risks. Although Malaysia has already developed and carried out programs of community awareness towards natural disasters, there is an urgent need for reassessing the existing programs for improvement to achieve zero losses in all forms $[6,7]$. In order to develop or improve suitable programs for communities with specific characteristics, the community's clear insight of the problem is crucial for them to prepare to face the disasters. Such preparedness can be gauged through KAP approach which studies the knowledge, attitude and practice of the community towards landslide [8]. This study aims to investigate community preparedness towards landslide by comparing three communities in Malaysia which are prone to landslide incidences.

\section{Background}

Pokharel (2005) defined landslide as the movement of soil or rock along a distinct surface of rupture, which separates the slide material from more stable underlying material [9]. Landslide refers to the ground movement like downward and outward movement of rock or soil mass. Malaysia like many other countries in the region suffers from the harm of several landslides [10] (see, Table 1). There are two main reasons for landslides in Malaysia. Besides landslide natural causes, the man-made reasons usually refer to development of hill slopes for housing, recreation, tourism, agriculture, highway as well as any other land changes (e.g. dam construction) [11] which is due to the process of urbanization and industrialization $[12,13]$. These causes are mainly originated from poverty, low residential and occupational mobility, and landlessness which lead to illegal squatting or farming on hill slopes and foothills and consequently increase vulnerability [14].

Table 1: Landslide Incidences in Malaysia

\begin{tabular}{ll|rl} 
Year & Place/ State & Year & Place/ State \\
\hline 1961 & Cameron Highlands, Pahang & 2006 & Ulu Klang, Selangor \\
\hline 1993 & Pantai Remis, Perak & 2007 & Kapit, Sarawak \\
\hline 1993 & Ulu Klang, Selangor & 2008 & Cameron Highlands, Pahang \\
\hline 1995 & Genting Highlands, Pahang & 2008 & Kajang, Selangor \\
\hline 1996 & Gua Tempurung, Perak & 2008 & Petaling Jaya, Selangor \\
\hline 1996 & Pos Dipang, Perak & 2008 & Terubong Jaya, Penang \\
\hline 1999 & Ulu Klang, Selangor & 2008 & Kuala Kubu Baru, Selangor \\
\hline 2002 & Ulu Klang, Selangor & 2008 & Jalan Semantan, Kuala Lumpur \\
\hline 2003 & Bukit Lanjan, Selangor & 2008 & Ulu Klang, Selangor \\
\hline
\end{tabular}

There are three phases in disaster management, namely, pre-disaster, emergency, and post-disaster management. This article addresses an important issue in the pre-disaster stage and specifically discusses the level of the 
community's preparedness towards landslide. In order to minimize the risks, the extent of the community's preparedness towards the disaster is crucial so that they can prepare and react accordingly. Thus, a program which is designed according to the characteristics of the society based on its basic demographical criteria is important for it to achieve identified objectives and generate better results.

\section{Objective Of The Paper}

Lack of knowledge about landslide is one of most determinative factors in low community awareness and consequently the high numbers of victims [15]. Most of the landslide studies are conducted to address technical issues, while the research on the community (local people) perspective is in short supply [16]. Solana and Kilburn (2003) urge that in planning landslide awareness programs, it is first necessary to determine residents' understanding of landslides [17]. Second, although many countries including Malaysia have general educational approach for disaster preparedness, there is still no exclusive plan for different regions with different characteristics. Thus, the main objective of this paper is to investigate the level of community preparedness towards landslide in three different communities in Malaysia which are all vulnerable towards landslide occurrence. The findings is hoped to assist the government, policy makers and other related parties in designing and implementing appropriate programs to prepare the community towards the disaster.

\section{Methodology}

Questionnaire survey is a popular and reliable method for acquiring information on public attitude, knowledge, and perception towards specific social issues [18]. Therefore, the study employs the same data collection approach for the same reason towards a specific environmental issue which is landslide. A set of questionnaires was developed focusing on nine demographical and two yes / no questions. The questionnaires items include gender, race, age, marital status, monthly income, employment status, employer, education level, type of housing area, "Has there been landslide incident near your area?" and "Have you ever experienced a landslide?" The questionnaires were distributed in three research sites, demonstrated in Table 2, namely Pos Dipang (Perak), Paya Terubung (Penang) and Ulu Kelang (Selangor). The three sites were selected based on two main reasons: first, all three sites are areas which are prone to experience landslide, and second, each one has specific and different social characteristics from one another which leads to variety of characteristics among respondents. In addition, all three communities have experienced landslide occurrences [19] which directly legitimize them as the research respondents. Pos Dipang which is situated in the state of Perak is an Orang Asli settlement site and famous for its 1996 landslide experience which resulted in many losses of lives and property. Paya Terubong, a small town located in Air Itam, Penang with a majority of middle income earners, have experienced similar disasters. It used to be a predominantly agricultural area but has transformed and become a working-class neighborhood. Ulu Klang is a well-liked residential area with a majority of upper class residents in Klang Valley, Selangor, and has faced several similar occurrences.

Table 2: Research Sites

\begin{tabular}{lll}
$\mathbf{1}$ & Pos Dipang & Penang \\
\hline $\mathbf{2}$ & Paya Terubung & Perak \\
\hline $\mathbf{3}$ & Ulu Kelang & Selangor \\
\hline
\end{tabular}

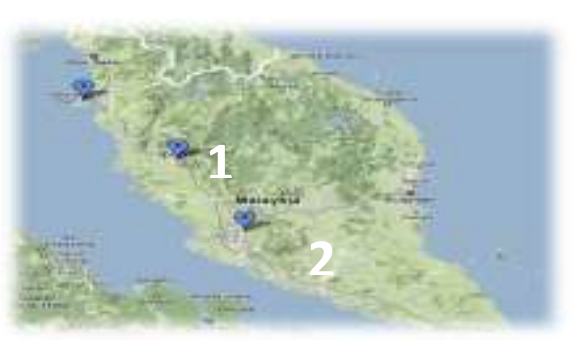

V. Data Analysis

The total number of returned questionnaires was 364 . Table 3 illustrates the distribution according to the number of respondents and the three research sites.

Table 3: Returned Questionnaires Distribution

\begin{tabular}{lll} 
Location & No. Respondent & Percent (\%) \\
\hline Group 1: Pos Dipang & 45 & $12.4 \%$ \\
Group 2: Paya Terubung & 175 & $48.1 \%$ \\
Group 3: Ulu Kelang & 143 & $39.3 \%$ \\
Missing value & 1 & $0.2 \%$ \\
\hline TOTAL & 364 & $100 \%$ \\
\hline
\end{tabular}


Table 4 describes the mean and standard deviation among the four constructs which are knowledge, attitude, practice and awareness.

Table 4: The Mean and Standard Deviation for Constructs

\begin{tabular}{lll} 
Domains & Mean & Standard Deviation \\
\hline Knowledge & 31.69 & 10.15 \\
Attitude & 34.21 & 10.56 \\
Practice & 13.53 & 4.50 \\
Awareness & 79.43 & 21.92 \\
\hline
\end{tabular}

The difference between the level of awareness, knowledge, attitude, and practice are examined by one-way analysis of variance to compare the mean score of respondents from three locations, namely, Pos Dipang, Paya Terubung and Ulu Kelang. The findings indicates that there are significant differences between the mean of awareness $(F(2,360)=33.79, p<.05)$, knowledge $(F(2,360)=33.40)$, attitude $(F(2,360)=17.45)$, and practice $(F(2,360)=25.65)$ scores of the three groups. A follow up Tukey HSD test shows that the mean for awareness, knowledge, attitude, and practice scores of Paya Terubung is significantly different from that of Pos Dipang and Ulu Kelang respondents (see Table 5). In particular, the analysis suggests that Paya Terubung residents have a significantly lower level of awareness about landslides when compared with residents from Pos Dipang and Ulu Kelang. Similarly, the analysis remarks that Paya Terubung residents have a significantly lower level of knowledge, attitude, and practice about landslides compared to the other two sites. Likewise, there is no significant difference between the residents of Pos Dipang and Ulu Kelang.

Table 5: Comparisons between the Research sites

\begin{tabular}{llll} 
& & Mean & Standard Deviation \\
\hline \multirow{4}{*}{ Awareness } & Pos Dipang & 81.73 & 14.18 \\
& Paya Terubung & 70.74 & 23.28 \\
& Ulu Kelang & 89.34 & 17.45 \\
\multirow{5}{*}{ Knowledge } & Pos Dipang & 32.80 & 4.96 \\
& Paya Terubung & 27.68 & 10.41 \\
& Ulu Kelang & 36.25 & 9.01 \\
\multirow{4}{*}{ Attitude } & Pos Dipang & 34.93 & 11.93 \\
& Paya Terubung & 31.09 & 11.93 \\
& Ulu Kelang & 37.80 & 8.01 \\
\multirow{5}{*}{ Practice } & Pos Dipang & 14.00 & 2.31 \\
& Paya Terubung & 11.97 & 5.00 \\
& Ulu Kelang & 15.29 & 3.60 \\
\hline
\end{tabular}

Table 6: Summary of One-way Anova

\begin{tabular}{lll} 
Variables & Significant Level $(P<.05)$ & Effect Size (Eta Squared) \\
\hline Awareness + Location & Yes & .16 (Large) \\
Knowledge + Location & Yes & .16 (Large) \\
Attitude + Location & Yes & .09 (Medium) \\
Practice + Location & Yes & .12 (Large) \\
\hline
\end{tabular}

Two-way ANOVA, Post-hoc comparison (i.e. Bonferroni, Tukey HSD and Games-Howell test) are utilized to figure out any significant effects of location and demographical data on entire constructs, namely attitude, knowledge, practice, and awareness. Tables 7, 8, 9 and 10 illustrate clearly the $p$ value and effect size.

\subsection{Attitude}

A two-way ANOVA was conducted to compare the attitude score of respondents in connection with location and demographical data. There is no statistically significant difference between different locations and races on the level of attitude. However, a Bonferroni test shows that the attitude of Malay respondents is significantly different from Chinese, while Indian respondents and others did not differ significantly from the Malay respondents. Again, there is no statistically significant main effect for location and age group. Besides, Bonferroni test shows that the mean score of the age group 18-29 and of age group 60+ differ significantly from each other. The result of comparison between location and marital status indicates that there is a statistically significant main and interaction effects with small effect size. Post-hoc comparisons also specify none of the 
marital status of the respondents differ significantly but the main effect of location, marital status and the interaction between them are significant.

Similarly, the comparison of attitude between location and income determines a statistically significant effect only for location with small effect size. A Bonferroni test indicates that the mean score for the income Group $6(+R M 10000)$ is significantly different from other group with lower income. In regards to employer, employment status and highest education level, there is only statistically significant effect for location with small effect size. The comparison could not show any statistically significant effect for location, types of house, and the interaction. Moreover, Bonferroni test indicates that double storey terrace house type of housing area is significantly different from that of flat (high rise building with units of residents). Likewise, Village house is significantly different from flat. Finally, for present or current housing area, post-hoc comparison indicates that highland is significantly different from flat land. The remaining housing areas do not show any significant difference.

Table 7: Summary of Two-way ANOVA: Attitude

\begin{tabular}{|c|c|c|c|c|c|c|c|}
\hline \multirow[t]{2}{*}{ Independent Variables } & \multicolumn{2}{|c|}{ Main Effects } & \multirow{2}{*}{$\begin{array}{l}\text { Effect } \\
\text { size }\end{array}$} & \multicolumn{2}{|c|}{$\begin{array}{l}\text { Interaction } \\
\text { effects }\end{array}$} & \multicolumn{2}{|l|}{ Post-hoc test } \\
\hline & $\mathrm{F}$ & $\mathrm{P}<.05$ & & $\mathrm{~F}$ & $\mathrm{P}<.05$ & Sig. between groups & $\mathrm{P}<.05$ \\
\hline Race & .59 & .63 & & 1.97 & .12 & Malay \& Chinese & .00 \\
\hline Age & .96 & .10 & $.06^{*}$ & 2.74 & $.01 *$ & Group18-29 \& 60+ & .01 \\
\hline Income & 2.03 & .08 & & 1.1 & .40 & $\begin{array}{l}>10000 \& 1000 \text { below } \\
>10000 \& 1001-2000 \\
>10000 \& 2001-3000 \\
>10000 \& 3001-5000\end{array}$ & $\begin{array}{l}.00 \\
.00 \\
.00 \\
.01\end{array}$ \\
\hline Marital Status & .72 & .50 & $.04 *$ & 3.3 & $.01 *$ & none & \\
\hline Employment Status & 1.2 & .31 & & 1.39 & .21 & none & \\
\hline Employer & .42 & .74 & & .76 & .55 & Government \& no employer & .00 \\
\hline $\begin{array}{l}\text { Highest } \\
\text { level }\end{array}$ & 2.2 & $.054 *$ & $.32 *$ & 1.53 & .17 & Not provided by analysis & - \\
\hline Types of house & 1.57 & .14 & & .43 & .73 & $\begin{array}{l}2 \text { storey terrace \& Flat } \\
\text { Village house \& Flat, }\end{array}$ & .00 \\
\hline Present Housing Area & .59 & .62 & $.03 *$ & 3.5 & $.02 *$ & Highlands \& Flat land & .00 \\
\hline
\end{tabular}

Table 8: Summary of Two-way ANOVA: Knowledge

\begin{tabular}{|c|c|c|c|c|c|c|}
\hline \multirow{2}{*}{$\begin{array}{l}\text { Independent } \\
\text { Variables }\end{array}$} & \multirow{2}{*}{$\begin{array}{l}\text { Main } \\
\text { Effects } \\
\text { F } \\
\end{array}$} & \multirow{2}{*}{$\begin{array}{l}\begin{array}{l}\text { Effect } \\
\text { size }\end{array} \\
\mathrm{P}<.05 \\
\end{array}$} & \multicolumn{2}{|c|}{ Interaction effects } & \multicolumn{2}{|l|}{ Post-hoc test } \\
\hline & & & $\mathrm{F}$ & $\mathrm{P}<.05$ & Sig. between groups & $\mathrm{P}<.05$ \\
\hline Race & 97 & .4 & 1.04 & .37 & $\begin{array}{l}\text { Malay \& Chinese, } \\
\text { Malay \& Indian, } \\
\text { Chinese \& Others }\end{array}$ & $\begin{array}{l}.00 \\
.00 \\
.01\end{array}$ \\
\hline Age & .87 & .5 & .74 & .66 & Group18-29 \& 30-39 & .00 \\
\hline Income & 2.13 & .06 & 1.45 & .23 & None & - \\
\hline Marital Status & 1.15 & .32 & .43 & .79 & Married \& unmarried & .00 \\
\hline Employment Status & 2.3 & .06 & .48 & .85 & Part time \& Student & .02 \\
\hline Employer & 93 & .42 & 46 & .76 & $\begin{array}{l}\text { Government \& private } \\
\text { Government \& personal } \\
\text { Government \& no employment. }\end{array}$ & $\begin{array}{l}.00 \\
.01 \\
.00\end{array}$ \\
\hline $\begin{array}{l}\text { Highest Education } \\
\text { level }\end{array}$ & 1.11 & .35 & 1.10 & .36 & Not provided by analysis & - \\
\hline Types of house & .42 & .89 & .76 & .52 & $\begin{array}{l}2 \text { storey terrace \& Flat } \\
2 \text { storey terrace \& Apart } \\
\text { Village house \& Flat, Village } \\
\text { house \& Apart }\end{array}$ & $\begin{array}{l}.01 \\
.00 \\
.00 \\
.00\end{array}$ \\
\hline $\begin{array}{l}\text { Present Housing } \\
\text { Area }\end{array}$ & 1.57 & 1.95 & .82 & .48 & $\begin{array}{l}\text { Highlands \& Flat land } \\
\text { Highland \& steep land }\end{array}$ & $\begin{array}{l}.00 \\
.02 \\
\end{array}$ \\
\hline
\end{tabular}




\section{$5.2 \quad$ Knowledge}

The following is a comparison of respondents' knowledge between location and demographical data on landslide. In respect of race, there is a statistically significant main effect for the three locations; however, the effect size is small. The main effect for race group and interaction effect are not significant. Post-hoc comparison indicates that, in terms of knowledge, Malay is significantly different from Chinese. Malay is also significantly different from Indian whereas Chinese is significantly different from others in this context. The comparison between location and age results statistically significant main effect for location with moderate effect size. Among different groups, the age group 18-29 years is significantly different in terms of location from age group 30-39 years although other age groups do not differ significantly. The effect of location and income reaches statistically significant difference with moderate effect size. Besides, Bonferroni test confirms that the knowledge of married respondents on landslide is significantly different from that of unmarried respondents, part time employment from student and unemployed respondents, and government employee from those who work in private sector. It is also significantly different from self-employed and no employment in this context.

The level of education effect on knowledge slightly varies across the three locations. There is a statistically significant main effect for location in terms of type of house, but the effect size is small. According to Bonferroni test, the knowledge of doubled storey terrace house residents towards landslide are significantly different from those who live in flat, and are significantly different from those in apartment. Similarly, the knowledge of village house people towards landslide is significantly different from those in flat and apartment. Given location and housing area, there is a significant main effect different location with moderate effect size but not the interaction effect. Bonferroni test indicates that the knowledge of people staying in highlands on landslide is significantly different from those in flat and steep land.

\subsection{Practice}

The following is a comparison between location and demographical data on practice based on the data collected. Similar to the study findings on knowledge towards landslide, the mean score for practice for that of Malay respondents is significantly different from Chinese. Practice of Malay respondents is also significantly different from Indian while Chinese respondents in terms of their practice on landslide issues are significantly different from others. In terms of age, there is a statistically significant main effect for location; however, the effect size is small. The interaction effect between location and age is significant as well. The mean score of 1829 age respondents is significantly higher compared to other age groups in Pos Dipang. Age group of 50-59 in Paya Terubung and age group of $60+$ in Ulu Kelang show the highest mean score. Given location and marital status, there is a statistically significant main effect for location (small effect size) but not for interaction. Posthoc comparisons indicate that the mean for practice score of married respondents is significantly different from unmarried. Other marital status (widow/widower) does not differ significantly. The analysis also suggests that the mean practice score of unmarried respondents is significantly higher than other means in Pos Dipang and Ulu Kelang.

In respect of location and income, there is a statistically significant main effect for location and income with small effect size. A follow-up Games-Howell test indicates that the mean score for the Income Group 6 (>RM 10000) of the respondents is significantly different from Group 1 (RM1000 and below), Group 2 (RM1001 -2000), Group 3 (RM2001-3000), Group 4 (RM3001 -5000). Other groups of income do not differ significantly. For employment status, there is a statistically significant main effect for location (moderate effect size), but not for interaction. Bonferroni test indicates that the mean score for practice of part time employment status respondents is significantly different from that of student but respondents of other employment status (full time, retire, unemployed) do not differ significantly. The analysis suggests that students have higher mean score for practice in comparison with other respondents. If observed by location, retired respondents in Ulu Kelang have the highest mean practice score, followed by unemployed respondents in Pos Dipang and retired respondents in Paya Terubung. There is a statistically significant main effect for location and employer even though the effect size is small. Bonferroni Post-hoc comparison test indicates that landslide practice of those who work with the government is significantly different from others.

There is a statistically significant main effect for location (small effect size) and highest education level (moderate effect size), but not interaction effect. Post-hoc comparison is not applicable because one group had fewer than two cases. In this context, it can be concluded that respondents with highest education level (degree) have higher mean score for practice compared to the others. There is a statistically significant main effect for location with small effect size, but not for types of house and the interaction between them. In this context, Bonferroni test shows that doubled storey terrace house is significantly different from flat and is also significantly different from apartment while village house people is significantly different from flat. The test also shows that highlands type of housing area is significantly different from flat land. The rest of indicators do not show any significant differences. 
Towards Community-based Landslide Preparedness in Malaysia

\begin{tabular}{|c|c|c|c|c|c|c|c|}
\hline \multirow{3}{*}{ Independent Variables } & \multicolumn{7}{|c|}{ Table 9: Summary of Two-way ANOVA: Practice } \\
\hline & \multicolumn{2}{|c|}{ Main Effects } & \multirow{2}{*}{ Effect size } & \multicolumn{2}{|c|}{ Interaction effects } & \multicolumn{2}{|l|}{ Post-hoc test } \\
\hline & F & $\mathrm{P}<.05$ & & F & $\mathrm{P}<.05$ & Sig. between groups & $\mathrm{P}<.05$ \\
\hline Race & .41 & .75 & & 1.31 & .82 & $\begin{array}{l}\text { Malay \& Chinese, } \\
\text { Malay \& Indian, } \\
\text { Chinese \& Others }\end{array}$ & $\begin{array}{l}.00 \\
.04 \\
.03\end{array}$ \\
\hline Age & 1.06 & .38 & $.06^{*}$ & 2.55 & $.01 *$ & None & \\
\hline Income & 2.33 & $.04 *$ & $.04 *$ & 1.0 & .40 & $\begin{array}{l}R M>10000 \& 1000 \text { below } \\
R M>10000 \& 1001-2000 \\
R M>10000 \& 2001-3000 \\
R M>10000 \& 3001-5000\end{array}$ & $\begin{array}{l}.05 \\
.00 \\
.01 \\
.01\end{array}$ \\
\hline Marital Status & .57 & .57 & & 1.80 & .13 & Married \& unmarried & .01 \\
\hline Employment Status & .45 & .77 & & .75 & .63 & Part time \& Student & .04 \\
\hline Employer & .48 & .70 & & .35 & .84 & $\begin{array}{l}\text { Government \& others } \\
\text { Private \& Others }\end{array}$ & $\begin{array}{l}.00 \\
.03\end{array}$ \\
\hline Highest Education level & 4.72 & .00 & $.06^{*}$ & 1.32 & .25 & Not provided by analysis & - \\
\hline Types of house & .42 & .89 & & .76 & .52 & $\begin{array}{l}2 \text { storey terrace \& Flat } \\
2 \text { storey terrace \& Apart } \\
\text { Village house \& Flat, }\end{array}$ & $\begin{array}{l}.00 \\
.03 \\
.00\end{array}$ \\
\hline Present Housing Area & 1.33 & .27 & & 1.41 & .24 & Highlands \& Flat land & .00 \\
\hline
\end{tabular}

\subsection{Awareness}

The comparison between location and demographical data on awareness are summarized as follows. There is a statistically significant main effect for location with large effect size, and the effect size is large but not for gender and the interaction effect. Bonferroni test discloses that the mean score for awareness of the respondents in Pos Dipang and Ulu Kelang are significantly different from those in Paya Terubung. Moreover, the mean awareness score is significantly higher in Ulu Kelang for both gender in comparison with Pos Dipang and Paya Terubung. In the same way, there is a statistically significant main effect for location (small effect size) but race and the interaction effect do not reach significant level. Post-hoc comparisons indicate that landslide awareness among the Malays is significantly different from the Chinese, and is significantly different from the Indian. Awareness among the Chinese is also significantly different from other races. Similar to gender and race, there is a statistically significant main effect for location (small effect size) but age and the interaction effect do not reach significant level. Post-hoc comparisons using the Tukey HSD test indicate that the mean awareness score for Pos Dipang is significantly different from Paya Terubung.

In terms of location and income, there is a significant main effect for location (moderate effect size) and six income groups (small effect size). Post-hoc comparisons using the Games-Howell test indicate that the mean awareness score for income group 2 (RM1001 -2000) of the respondents is significantly different from group 6 (RM10000). Other groups of income do not differ significantly. While the main effect for location is significant (moderate effect size), the main effect for respondents' marital status and the interaction effect do not reach statistical significance. Post-hoc comparisons confirm that the mean awareness score of married respondents is significantly different from unmarried respondents in this context. Other marital status (widow/widower) did not differ significantly with either married or unmarried respondents. For employment status, there is a statistically significant main effect for location (small effect size) but not for interaction effect. Post-hoc comparisons indicate that part time respondents is significantly different from student, but other employment status of respondents (full time, retire, employed) did not differ significantly in terms of landslide awareness.

There is a statistically significant main effect for location (moderate effect size) whereas employer type and the interaction effect do not reach significant level. Post-hoc comparisons show that landslide awareness among those who work with the government is significantly different from those in private, self-employed and none. There is also a statistically significant main effect for location and highest education level (both with small effect size) but not for the interaction effect. Post-hoc comparisons could not be applied since one category has fewer than two cases. There is a statistically significant main effect for location (small effect size) whereas insignificant for type of house and the interaction. Bonferroni test indicates that landslide awareness of those who live in doubled storey terrace house is significantly different from those in flat house and apartment. Similarly, awareness of those in the village house is significantly different from those in flat and apartment. Finally, Post-hoc comparisons confirm highland residents have significantly different awareness from those in flat and steep lands. 
Towards Community-based Landslide Preparedness in Malaysia

\begin{tabular}{|c|c|c|c|c|c|c|c|}
\hline \multicolumn{8}{|c|}{ Table 10: Summary of Two-way ANOVA: Awareness } \\
\hline \multirow{2}{*}{$\begin{array}{l}\text { Independent } \\
\text { Variables }\end{array}$} & \multicolumn{2}{|c|}{ Main Effects } & \multirow[t]{2}{*}{$\begin{array}{l}\text { Effect } \\
\text { size }\end{array}$} & \multicolumn{2}{|c|}{$\begin{array}{l}\text { Interaction } \\
\text { effects }\end{array}$} & \multicolumn{2}{|l|}{ Post-hoc test } \\
\hline & F & $\mathrm{P}<.05$ & & F & $\mathrm{P}<.05$ & Sig. between groups & $\mathrm{P}<.05$ \\
\hline Race & .93 & .43 & & 1.61 & .20 & $\begin{array}{l}\text { Malay \& Chinese, } \\
\text { Malay \& Indian, } \\
\text { Chinese \& Others }\end{array}$ & $\begin{array}{l}.00 \\
.04 \\
.01\end{array}$ \\
\hline Age & .93 & .45 & & 1.91 & .06 & Group18-29 \& 30-39 & .04 \\
\hline income & 2.64 & $.02 *$ & $.04 *$ & 1.07 & .36 & RM>10000 \& 1001-2000 & .01 \\
\hline Marital Status & 1.05 & .35 & & 1.51 & .20 & Married \& unmarried & .00 \\
\hline Employment Status & 1.85 & .12 & & .76 & .62 & Part time \& Student & .04 \\
\hline Employer & .69 & .56 & & .57 & .69 & $\begin{array}{l}\text { Government \& private } \\
\text { Government \& personal } \\
\text { Government \& no emp. }\end{array}$ & $\begin{array}{l}.01 \\
.02 \\
.00\end{array}$ \\
\hline $\begin{array}{l}\text { Highest Education } \\
\text { level }\end{array}$ & 2.26 & $.049^{*}$ & $.03 *$ & 1.46 & .19 & Not provided by analysis & - \\
\hline Types of house & 1.02 & .42 & & .21 & .89 & $\begin{array}{l}2 \text { storey terrace \& Flat } \\
2 \text { storey terrace \& Apart } \\
\text { Village house \& Flat, Village } \\
\text { house \& Apart }\end{array}$ & $\begin{array}{l}.00 \\
.00 \\
.00 \\
.01\end{array}$ \\
\hline $\begin{array}{l}\text { Present } \\
\text { Area }\end{array}$ & 1.31 & 27 & & 2.28 & .08 & $\begin{array}{l}\text { Highlands \& Flat land } \\
\text { Highland \& steep land }\end{array}$ & $\begin{array}{l}.00 \\
.04\end{array}$ \\
\hline
\end{tabular}

\section{Discussion}

As mentioned earlier, the study focuses on demographic characteristics to gauge the community's level of preparedness towards landslide incidences. This is imperative to act as guideline for preparedness program development in each region. As expected, there is a significant difference between the locations for all constructs. Interestingly, the area with lower landslide experience has less mean score in all constructs. On the other hand, the area with high-class residents in terms of education and jobs has higher mean score in the entire constructs. Furthermore, the higher awareness level is significantly correlated with the number of landslide experience in the area. Practice has received less attention in all areas compared to means, thus preparedness program should focus on linking the attitude to the actions to increase landslide awareness in the communities. For all sites, the highest education level has significant relationship with attitude and practice and partially with knowledge and accordingly with awareness. Gender, race, age, marital status, monthly income, employment status, and employer do not pose as an issue in the relationship with all constructs in two research sites; Ulu Kelang and Paya Terubung. In contrast, gender, age, marital status, and employment status have significant relationship respectively with some or all constructs in Pos Dipang. However, changing attitude by gender, age, and practice by age and marital status, or awareness by age and employment status can be inferred as underlying differences between various social groups in Pos Dipang. Accordingly, it signifies the need of different approaches in landslide preparedness program in this area.

The analysis also suggests that race is not a vital factor in indicating awareness and other constructs since there is no difference in scores for Malay, Chinese and Indian respondents. It means development program does not need to tailor specific program for different races in different locations. In particular, there is no effect of race and location on respondents' attitude. However, Malay respondents have higher knowledge and practice scores about landslide in comparison with other races. In the context of formal and informal education programs, results prove that respondents of 18-29 age group have significantly higher knowledge on landslide in contrast with other age group, especially group 30-39. However, statistical evidence shows that there is a difference in scores for respondents from the three locations. This proof remarks the need of special program for the average age especially for Pos Dipang area. There is also a significant interaction between location and age groups for practice. For example in Ulu Kelang, experienced people have more knowledge towards landslides. This fact suggests different approaches of awareness program should be employed based on the age group in different areas.

In general, the analysis suggests that income of the respondents do not significantly determine their attitude, knowledge or awareness towards landslide. Nevertheless, the analysis suggests that respondents of income RM>10000 have significantly better practice towards landslide compared to respondents of other income groups. On the other hand, income also has a positive effect on practice and awareness for income range between RM1001 and RM2000. As predicted, the results prove the need of more focus program for low-income groups. 
There is no effect of marital status and location on respondents' knowledge. In addition, there is no significant interaction between location and marital status of respondents on the knowledge about landslide. Marital status also does not affect attitude although there is an interaction between location and marital status. It also addresses the need of specific theme for developing positive attitude and practice in each area. There should be more emphasis on married people since the unmarried residents have higher level of practice and awareness based on age and knowledge.

Similarly, respondents' employer does not have any significant influence on the attitude and knowledge score towards landslide. The analysis suggests that there is no significant interaction between location and employment status of respondents on the knowledge and attitude as well. Given awareness, all types of employer of Ulu Kelang respondents are significantly higher compared to those of Paya Terubung and Pos Dipang. Similarly, the respondents for all types of employers in Ulu Kelang have significantly higher mean practice score in compared with those in Pos Dipang and Paya Terubung. This fact confirms the positive role of organization and employer or working environment to increase the awareness as a general theme. On the other hand, the higher mean score for practice among the students confirms the positive role of preparedness program in the Malaysian educational system.

Overall, highest education level has a significant impact on awareness, knowledge and practice. The highest education level does not determine high attitude score on landslide for the three locations. In contrary, the analysis determines a difference in awareness scores for respondents from different locations and different education level. However, there is no interaction effect, which means no effect of location on awareness for respondents with highest education level.

Types of housing area have no impact on respondents' knowledge. However, it has a relationship with attitude. Respondents who live in doubled storey terrace house have significantly better attitude towards landslide in comparison with flat inmates and the villagers. If the type of house reflects incomes, then the relationship can be justified by the correlation between income and attitude. It can be concluded that preparedness plan should focus on those in village houses more than people of the other types of housing areas.

In accordance of the significant interaction between location and present housing area on the attitude, the study concludes that respondents from flatland have higher mean of attitude compared to respondents who live in highlands. Vulnerable housing areas have less awareness and hence need more attention towards landslide awareness programs. Besides, regarding knowledge, there is no need for different approaches for different locations since there is no significant interaction between location and present housing area. There is no effect of present housing area on respondents' knowledge and awareness while the effect for location is significant for knowledge and not awareness. Finally, in terms of landslide practice, people who live in highland need more attention in increasing their level of landslide practice compared to those of flat land residents.

\section{Conclusion}

This study investigates the relationship between demographic characteristics and individual landslide awareness as underpinning principles for disaster preparedness program. The results address differences between attitude, knowledge, practice, and awareness in three vulnerable areas. Demographical data is collected based on gender, race, age, marital status, monthly income of respondent, employment status, employer, highest education level, types of housing area, present housing area, incidence of landslide and experience of a landslide. The results remark significant difference between these regions. Therefore, the necessity of different preparedness approaches should be highlighted. This upshot suggests community-based programs should be designed along with national disaster management strategy to cope with local and cultural values of each community more effectively.

\section{Acknowledgements}

The writers would like to extend greatest appreciations to Research University (RU) Grant Landslide Management, Information and Policy, Universiti Sains Malaysia (USM) for funding the project. This article is one of the stated tangible outputs. The writers also acknowledge contributions in different forms from other coresearchers and individuals who assisted directly or indirectly towards the completion of the paper.

\section{References}

[1] D. Karnawati, and S. Pramumijoyo, Strategy for promoting education for natural disaster reduction in Indonesia and ASEAN region. The First World Landslide Forum, 2008, 265-268.

[2] M. Dorasamy, M. Raman, S. Muthaiyah, and M. Kaliannan, Investigating perceived ICT usefulness for disaster readiness: A preliminary analysis. $20117^{\text {th }}$ International Conference on IT in Asia (CITA), Kuchig, Sarawak, 2011, 1-7.

[3] R, Kohli, Socio-political approach to disaster management by community participation. Unpublished Thesis, 2005.

[4] J. J. Pereira, C. H. Tan, I. Komoo, Chapter 8: Mainstreaming climate change adaptation and disaster risk reduction: A Malaysian approach, Rajib Shaw, Juan M. Pulhin, Joy Jacqueline Pereira, in (ed.) Climate Change Adaptation and Disaster Risk Reduction: An Asian Perspective (Community, Environment and Disaster Risk Management, Volume 5), (Emerald Group Publishing Limited, 2010, 147 - 167. 
[5] N. Gurung, Living with landslides and awareness raising: Case examples from Laprak Landslide, Gorkha, and Aaula Rockfall, Myagdi, Nepal. The First World Landslide Forum, 2008, 485-489.

[6] S. H. Danan, F. Lavigne, J. Sartohadi, P. Hadi, and Winaryo, Landslide hazard and risk assessment and their application in risk management and landuse planning in eastern flank of Menoreh Mountains, Yogtakarta Province, Indonesia. Natural Hazards, 2010, 623-642.

[7] O. C. Austin, and Amir Hussin Baharuddin, Risk in Malaysian agriculture: The need for a strategic approach and a policy refocus, Kajian Malaysia, 2012, 30(1), 21-50.

[8] S. H. Danan, F. Lavigne, J. Sartohadi, P. Hadi, and Winaryo, Landslide hazard and risk assessment and their application in risk management and landuse planning in eastern flank of Menoreh Mountains, Yogtakarta Province, Indonesia. Natural Hazards, 2010, 623-642.

[9] R. Pokharel, Community response to landslide in Syuchatar VDC. School of Environmental Management and Sustainable Development, 2005, 1-16.

[10] Badaruddin A. Rahman, Issues of disaster management preparedness: A case study of directive 20 of National Security Council Malaysia, International Journal of Business and Social Science, 2012, 3(5), 85-92.

[11] N. W. Chan, Responding to landslide hazards in rapidly developing Malaysia: a case of economics versus environmental protection. Disaster Prevention and Management , 7 (1), 1998, 14-27.

[12] J. J. Pereira, C. H. Tan, I. Komoo, Chapter 8: Mainstreaming climate change adaptation and disaster risk reduction: A Malaysian approach, Rajib Shaw, Juan M. Pulhin, Joy Jacqueline Pereira, in (ed.) Climate Change Adaptation and Disaster Risk Reduction: An Asian Perspective (Community, Environment and Disaster Risk Management, Volume 5), (Emerald Group Publishing Limited, 2010, $147-167$.

[13] C. P. Tseng, and C. W. Chen, Natural disaster management mechanisms for probabilistic earthquake loss, Natural Hazards, 60 (2012), 1055-1063.

[14] N. W. Chan, Responding to landslide hazards in rapidly developing Malaysia: a case of economics versus environmental protection. Disaster Prevention and Management , 7 (1), 1998, 14-27.

[15] D. Karnawati, and S. Pramumijoyo, Strategy for promoting education for natural disaster reduction in Indonesia and ASEAN region. The First World Landslide Forum, 2008, 265-268.

[16] R. Pokharel, Community response to landslide in Syuchatar VDC. School of Environmental Management and Sustainable Development, 2005, 1-16.

[17] M. C. Solana, and C. Kilburn, Public awareness of landslide hazards: the Barranco de Tirajana, Gran Canaria, Spain. Geomorphology, 2003, 54, 39-48.

[18] D. K. Bird, The use of questionnaires for acquiring information on public perception of natural hazards and risk mitigation - a review of current knowledge and practice. Natural Hazards and Earth System Sciences , 9, 2009, 1307-1325.

[19] N. W. Chan, Responding to landslide hazards in rapidly developing Malaysia: a case of economics versus environmental protection. Disaster Prevention and Management , 7 (1), 1998, 14-27. 